\title{
THE ROLE OF TOURISM IN THE FACTORS SYSTEM OF SOCIO-ECONOMIC DEVELOPMENT OF THE REGION
}

\author{
Saglara B. Boldyreva \\ Kalmyk State University named after B.B. Gorodovikova, Elista, Russian Federation
}

\begin{abstract}
At the current stage of social development, the choice of strategic priorities for regional development requires a careful analysis of the factors, the choice and justification of those that can become sources of growth in the level of social and economic development of the region. The increase in the level of socio-economic development, the transition to its new stages and formations, accompanies processes and trends that increase the importance of individual sectors in the socio-economic development of the region.

Such industries can become one of the main factors of the region's competitiveness, increase of its socio-economic development level, economic specialization in the domestic and international economic space. Among modern trends, which should be noted when choosing the sources of economic growth in the regions can be identified: the creation of conditions for a comfortable life, the desire of society to rationalize the use of natural and recreational resources, increase labor productivity, changes in culture and the value system of the population, increase mobility of the population.

In such circumstances, tourism becomes a sector that can become a source of social and economic development of the region.

Key words: region, tourism, factors of social and economic development of the region, the role of tourism.

Citation. Boldyreva S.B. The Role of Tourism in the Factors System of Socio-Economic Development of the Region. Vestnik Volgogradskogo gosudarstvennogo universiteta. Seriya 3, Ekonomika. Ekologiya [Science Journal of Volgograd State University. Global Economic System], 2018, vol. 20, no. 4, pp. 77-89. (in Russian). DOI: https:// doi.org/10.15688/jvolsu3.2018.4.8
\end{abstract}

УДК 332.122

ББК 65.04
Дата поступления статьи: 01.10.2018

Дата принятия статьи: 26.11.2018

\section{ЗНАЧЕНИЕ ТУРИЗМА В СИСТЕМЕ ФАКТОРОВ СОЦИАЛЬНО-ЭКОНОМИЧЕСКОГО РАЗВИТИЯ РЕГИОНА}

\author{
Саглара Борисовна Болдырева
}

Калмыцкий государственный университет им. Б.Б. Городовикова, г. Элиста, Российская Федерация

\footnotetext{
Аннотация. Предмет/тема. На современном этапе общественного развития выбор стратегических приоритетов регионального развития требует тщательного анализа факторов, выбора и обоснования тех из них, которые могут стать источниками роста уровня социально-экономического развития региона. Повышение уровня общественно-экономического развития, переход к его новым этапам и формациям сопровождают процессы и тенденции, повышающие значимость отдельных отраслей в социально-экономическом развитии региона. Такие отрасли могут стать одним из основных факторов конкурентоспособности региона, повышения уровня его социально-экономического развития, экономической специализации во внутреннем и международном экономическом пространстве. Среди тенденций современности, на которые стоит обратить внимание при выборе источников экономического роста регионов, можно выделить: создание условий для комфортной жизнедеятельности, стремление общества к рационализации использования природных и рекреационных ресурсов, рост производительности труда, изменения в культуре и системе ценностей населения, повышение мобильности населения.

В таких условиях отраслью, способной стать источником социально-экономического развития региона, становится туризм.
} 
Цели/задачи. Целью проведенного исследования является поиск принципов и методических подходов повышения роли туризма в системе факторов социально-экономического развития региона.

Задачи данной работы:

- исследование методологии в подходах оценки факторов социально-экономического развития региона;

- изучение методологических принципов в определении критериев классификации факторов устойчивого социально-экономического развития региона;

- определение методики оценки состояния туризма в регионе и его влияния на социально-экономическое развитие.

Методология. В процессе исследования были использованы экономико-математические методы; методы сравнения, которые позволили автору исследовать основы оценки влияния туризма на социальноэкономическое развитие региона с позиции методологии.

Результаты. Проведенные автором ранее исследования по этой проблеме неоднократно докладывались и обсуждались на конференциях различного уровня, в том числе и международного. Результаты научного исследования внедрены в учебный процесс по дисциплине «Региональная экономика».

Выводы/значимость. Таким образом, оценка социально-экономического развития региона, основанная на измерении вклада каждого фактора в достижение целей социально-экономического развития, уточнения уровня социально-экономического развития, становится необходимым научным и прикладным действием, этапом и процессом в ходе обеспечения устойчивого социально-экономического развития региона.

Ключевые слова: регион, туризм, факторы социально-экономического развития региона, роль туризма.

Цитирование. Болдырева С. Б. Значение туризма в системе факторов социально-экономического развития региона // Вестник Волгоградского государственного университета. Серия 3, Экономика. Экология. 2018. - T. 20, № 4. - C. 77-89. - DOI: https://doi.org/10.15688/jvolsu3.2018.4.8

В условиях недостаточной эффективности сложившихся подходов к пространственному развитию формируются новые парадигмы и концепции. Согласимся с авторами в том, что первостепенно значимой задачей в таких условиях становится «задача пересмотра приоритетов, сложившихся ранее в региональной экономике- профилирующих видов деятельности, которые оказались неспособными продолжать выполнять роль локомотива экономики» [9, с. 28].

Выбор факторов социально-экономического развития регионов во многом связан с подходом или доктриной, в рамках которой выполняются научные исследования. К примеру, согласно положениям либеральной доктрины, основным фактором регионального развития являются рынки, а динамика параметров развития территории является производной рыночного развития. Представители другого подхода основными факторами регионального развития называют взаимосвязанное и взаимозависимое развитие производительных сил и производственных отношений с точки зрения такого подхода рынок выступает частностью, формой производственных отношений [16, с. 154-155].

В.И. Видяпин предлагает решать проблему выбора фундаментальных факторов развития территории через формулу «создатель - созданное - природное», где под «со- здателем» подразумевается личность, под созданным - в основном материальные результаты деятельности личности, под «природным» - природные богатства как фактор регионального развития [12, с. 157].

В современных условиях (в том числе начиная с середины 1990-х гг.) долгосрочное развитие региональных социально-экономических систем в России осуществляется в рамках концепции устойчивого развития [15]. В связи с этим систематизация факторов социально-экономического развития региона не может не учитывать данного обстоятельства. Можно констатировать, что в исследованиях научного и прикладного характера на современном этапе происходит постепенное смещение содержания вопросов стратегического развития регионов в пользу формирования основных групп условий для устойчивого развития или сбалансированного развития общества, экономики и природы территории. Об этом свидетельствует содержание основополагающих нормативных правовых актов [17] и методических документов, регулирующих вопросы стратегического планирования развития территорий.

Под фактором понимают движущую силу, причину, условия, параметры и показатели, оказывающие влияние на тот или иной процесс [1;2]. 
Классификация факторов устойчивого социально-экономического развития региона осуществляется в научных исследованиях на основе различных подходов и методологических оснований. К примеру, в работе [7] с использованием структурно-балансового подхода выделяются следующие факторы устойчивого социально-экономического развития региона:

- хозяйственная устойчивость региона определяется инновационностью бизнес-процессов в регионе, снижением показателей энерго-, фондо- и материалоемкости регионального продукта, совершенствованием организации бизнес-процессов в регионе;

- устойчивость деловой среды региона, которая связана с повышением уровня деловой активности субъектов региональных рынков, нематериальными активами, повышением эффективности стратегии и тактики регионального хозяйствования;

- финансовая устойчивость региона, характеризующаяся оптимизацией состава источников финансирования, финансового мониторинга регионального хозяйства и состава финансовых активов региона;

- экологическая устойчивость, проявляющаяся в снижении выбросов и сбросов загрязняющих веществ, рациональном природопользовании, сокращении объемов твердых отходов;

- управленческая устойчивость региона, которая определяется оптимизацией объема и структуры ресурсной базы территории, активизацией компетентностного подхода к развитию трудовых ресурсов региона, повышением эффективности региональных социально-экономических программ;

- многоуровневая конкурентоспособность региона, связанная с благоприятным инвестиционным климатом, повышением удельного веса ВРП в ВНП и ростом качественных характеристик ВРП [3, с. 11].

Приведенный подход, возможно, и представляет интерес с точки зрения обеспечения узконаправленных задач диагностирования, но не отражает всех граней и факторов социально-экономического развития региона.

В исследовании Н.В. Невейкиной к числу факторов, определяющих устойчивость социально-экономического развития региона, отнесены такие группы, как территориальный, административный, экономический, институциональный, организационный и демографический $[12$, с. 22]. Нельзя в полной мере согласиться с предлагаемым содержанием каждого фактора (включен автором в соответствующие «идентификационные пространства»). К примеру, в группу административных факторов указанный автор относит геополитическое положение региона, качество регионального менеджмента, открытость органов региональной власти для диалога с обществом, доходы регионального бюджета, региональную нормативную правовую базу [8, c. 22]. Организационные факторы ограничиваются только социальной и предпринимательской инфраструктурой. В состав территориальных факторов частично включены природно-климатические. В состав демографических факторов включена экологическая обстановка в регионе. Достоинством предложенной автором иерархической системы факторов регионального развития можем назвать их выделенные характеристики (контролируемость, пространственность, ограниченность, мобильность) и оригинальную группировку факторов в соответствии с выделенными характеристиками.

О. Скотаренко [13, с. 250-253] делит факторы социально-экономического развития на объективные (неуправляемые) и субъективные (управляемые). К числу неуправляемых факторов автор почему-то относит государственную региональную политику, имея, видимо, в виду, что она не поддается управлению и контролю региональных властей. Тем не менее такое понимание видится не вполне корректным, и следует говорить скорее о фактоpax частичной управляемости. Полагаем, что ставить в один ряд неуправляемых факторов с государственной региональной политикой географическое положение, природно-климатические условия, доступ к сырьевым ресурсам - не вполне корректно.

В других исследованиях [18, с. 162-176; 19] выделяются экономические, социальные, институциональные, инновационные и глобализационные факторы. И в данном случае вызывают вопросы принципы, которыми руководствовались авторы при раскрытии содержания каждой из групп факторов. К при- 
меру, в число экономических факторов попали технология и организация производства, количество и качество природных ресурсов. Среди социальных факторов значатся явно демографические, например, численность населения. К институциональным факторам отнесен менталитет населения. Среди глобализационных факторов сделан акцент на участии только в одном международном сообществе и др.

Методологические ошибки при построении теоретических конструктов системы факторов социально-экономического развития региона в дальнейшем могут повлиять на выбор эффективных механизмов управления социально-экономическим региональным развитием.

Ю.Н. Шедько на основе комплексного подхода указывает на целесообразность сочетания таких характеристик устойчивости регионального развития, как институциональная, социальная, экономическая, экологическая и финансовая [20].

Существуют и ограниченные (по группам исследуемых факторов), «абстрактно-урезанные» подходы к выделению факторов социально-экономического развития. По мнению исследователей [9], ключевую роль в развитии экономики территории играют факторы, оказывающие влияние на формулирование целей управления:
- объективные потребности территориальной социально-экономической системы на конкретном этапе ее развития;

- ресурсные возможности для удовлетворения этих потребностей;

- содержание государственной и региональной политики, определяющих приоритеты в решении проблем территориального развития [9].

В таблице 1 сведены различные способы классификации факторов социально-экономического развития территории.

На наш взгляд, характерные для нынешнего этапа общественного развития факторы могут оказывать равносильное влияние на уровень социально-экономического развития региона. Безусловно, для каждой конкретной территории степень влияния отдельных групп факторов на социально-экономическое развитие может различаться.

Учитывая данное утверждение, предлагаем классифицировать факторы социальноэкономического развития территории следующим образом (см. рис. 1).

Так, к основным группам факторов социально-экономического развития территории отнесены:

- качество администрирования на центральном и региональном уровне;

- состояние экономики и отраслевого развития;

Обзор подходов к классификации факторов

Таблииа 1

\begin{tabular}{|c|c|}
\hline Авторы & Факторы \\
\hline $\begin{array}{l}\text { Е.Д. Игнатьева, } \\
\text { О.С. Мариев, } \\
\text { А.Е. Ширманова } \\
{[5, \text { с. 97-99] }}\end{array}$ & Экономические, социальные, демографические, финансовые \\
\hline Н.В. Невейкина [8] & $\begin{array}{l}\text { Экономические, институциональные, демографические, ад- } \\
\text { министративные, организационные, политические }\end{array}$ \\
\hline И.А. Масюто [6] & $\begin{array}{l}\text { Экономические, социальные, экологические, финансовые, } \\
\text { правовые, политические, бюджетные }\end{array}$ \\
\hline А.В. Орлова [10] & $\begin{array}{l}\text { Природно-сырьевая составляющая, производственные, эконо- } \\
\text { мические, факторы человеческого потенциала, инфраструк- } \\
\text { турные, инновационные }\end{array}$ \\
\hline А.И. Татаркин [14] & Экономические, социальные, технологические, экологические \\
\hline А.А. Чуб [19] & $\begin{array}{l}\text { Социальные, экономические, институциональные, иннова- } \\
\text { ционные, глобализационные }\end{array}$ \\
\hline
\end{tabular}

Примечание. Составлено автором. 
С.Б. Болдырева. Значение туризма в системе факторов социально-экономического развития региона

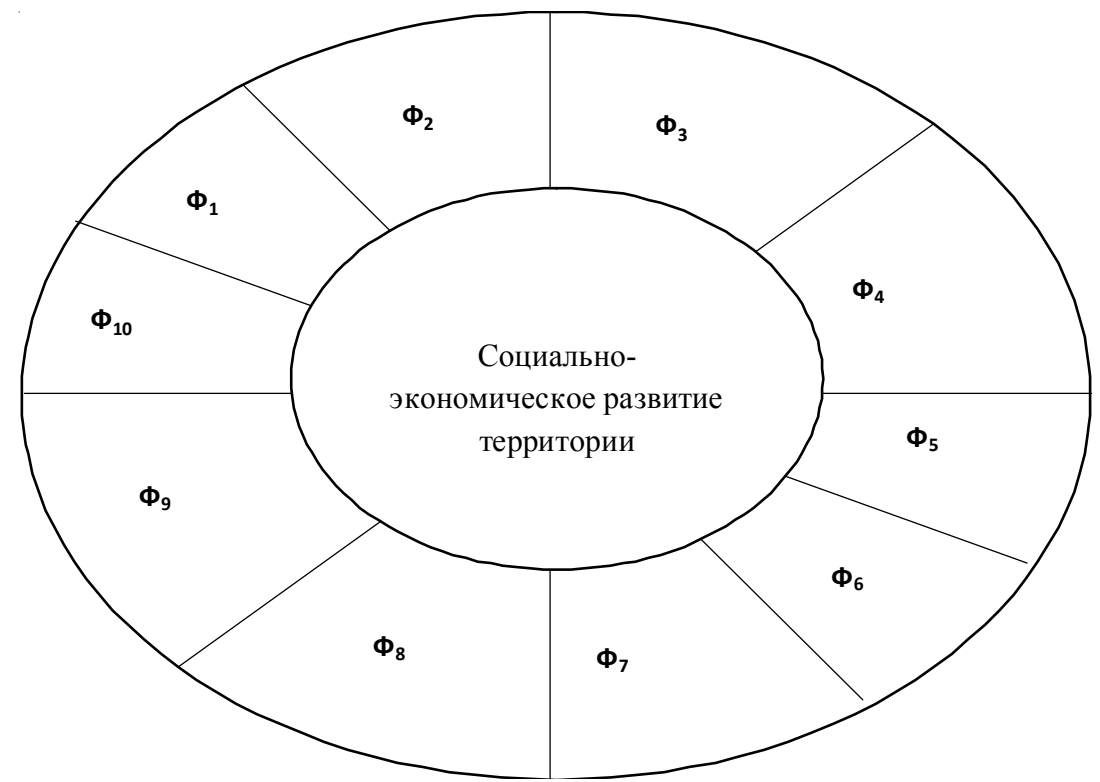

Рис. 1. Система факторов социально-экономического развития региона ${ }^{1}$

Примечание. Составлено автором.

- состояние финансовой подсистемы региона; тенциал;

- трудовые ресурсы и человеческий по-

- состояние объектов материальной и нематериальной инфраструктуры;

- демографическая ситуация и демографическая структура;

- социальные и культурные условия;

- политико-правовой и институциональный фактор;

- территориальное положение (географический фактор);

- природно-климатические условия.

Раскроем содержание каждого из приведенных групп факторов.

Первая группа факторов - качество администрирования на центральном и региональном уровне - выведены в самостоятельные условия социально-экономического развития территорий, поскольку в зависимости от данного фактора находится возможность раскрытия потенциала остальных девяти групп факторов. Используя специальные методы воздействия на региональное развитие, субъекты управления преобразуют скрытые ресурсы каждого фактора в конечные результаты социально-экономического развития. Данная группа факторов является полностью управляемой и контролируемой. Однако степень управляемости и контроля зависит от уровня управления - центрального или регионального. Безусловно, на уровне территории часть функций управления ее развитием ограничена, что позволяет говорить о частичной управляемости.

На рисунке 2 приведено содержание фактора «качество администрирования на центральном и региональном уровнях».

Вторая группа факторов «состояние экономики и отраслевого развития» также относится к управляемой и отражает, во-первых, комплексное влияние параметров экономического состояния региона на его социально-экономическое развитие, во-вторых, влияние основных групп отраслей территориальной экономики на региональное развитие. Содержание фактора проиллюстрировано на рисунке 3 .

В самостоятельный, управляемый фактор социально-экономического развития региона нами также выделено состояние финансовой подсистемы региона. Влияние данного фактора на социально-экономическое развитие региона состоит в решении задач эффективного аккумулирования и распределения финансовых ресурсов для целей регионального развития. Содержание элементов фактора приведено на рисунке 4.

Фактор, характеризующий трудовые ресурсы и человеческий потенциал, также относится к управляемому. Данный фактор тесно связан с демографическим, но также потребовал выделения в самостоятельную группу в силу своей специфики. 
Содержание фактора «качество администрирования на центральном и региональном уровне» $\left(\Phi_{1}\right)$

\begin{tabular}{|c|c|}
\hline Центральный уровень управления & Региональный уровень управления \\
\hline $\begin{array}{c}\text { Стратегические документы } \\
\text { долгосрочного } \\
\text { пространственного развития }\end{array}$ & $\begin{array}{c}\text { Региональное стратегическое видение } \\
\text { долгосрочного развития }\end{array}$ \\
\hline $\begin{array}{c}\text { Механизмы распределения } \\
\text { функций между центральными } \\
\text { и региональными органами } \\
\text { управления }\end{array}$ & $\begin{array}{c}\text { Выбранная организационная } \\
\text { структура органов региональной } \\
\text { власти и распределения функций } \\
\text { между ветвями власти }\end{array}$ \\
\hline $\begin{array}{c}\text { Распределение ресурсов } \\
\text { для территорий }\end{array}$ & $\begin{array}{c}\text { Сложившаяся практика } \\
\text { использования ресурсов } \\
\text { для регионального развития }\end{array}$ \\
\hline $\begin{array}{c}\text { Пределы функций } \\
\text { территориальных субъектов } \\
\text { управления по воздействию на } \\
\text { объекты управления }\end{array}$ & $\begin{array}{c}\text { Пределы функций субъектов } \\
\text { управления на локальном уровне }\end{array}$ \\
\hline $\begin{array}{c}\text { Механизмы контроля и } \\
\text { мониторинга реализуемой } \\
\text { системы целей и задач } \\
\text { территориального развития }\end{array}$ & $\begin{array}{c}\text { Механизмы контроля, мониторинга и } \\
\text { оценки эффективности реализуемых } \\
\text { долгосрочных программ и текущих } \\
\text { задач }\end{array}$ \\
\hline
\end{tabular}

Рис. 2. Содержание элементов фактора социально-экономического развития территории «качество администрирования на центральном и региональном уровне» $\left(\Phi_{1}\right)$

Примечание. Составлено автором.

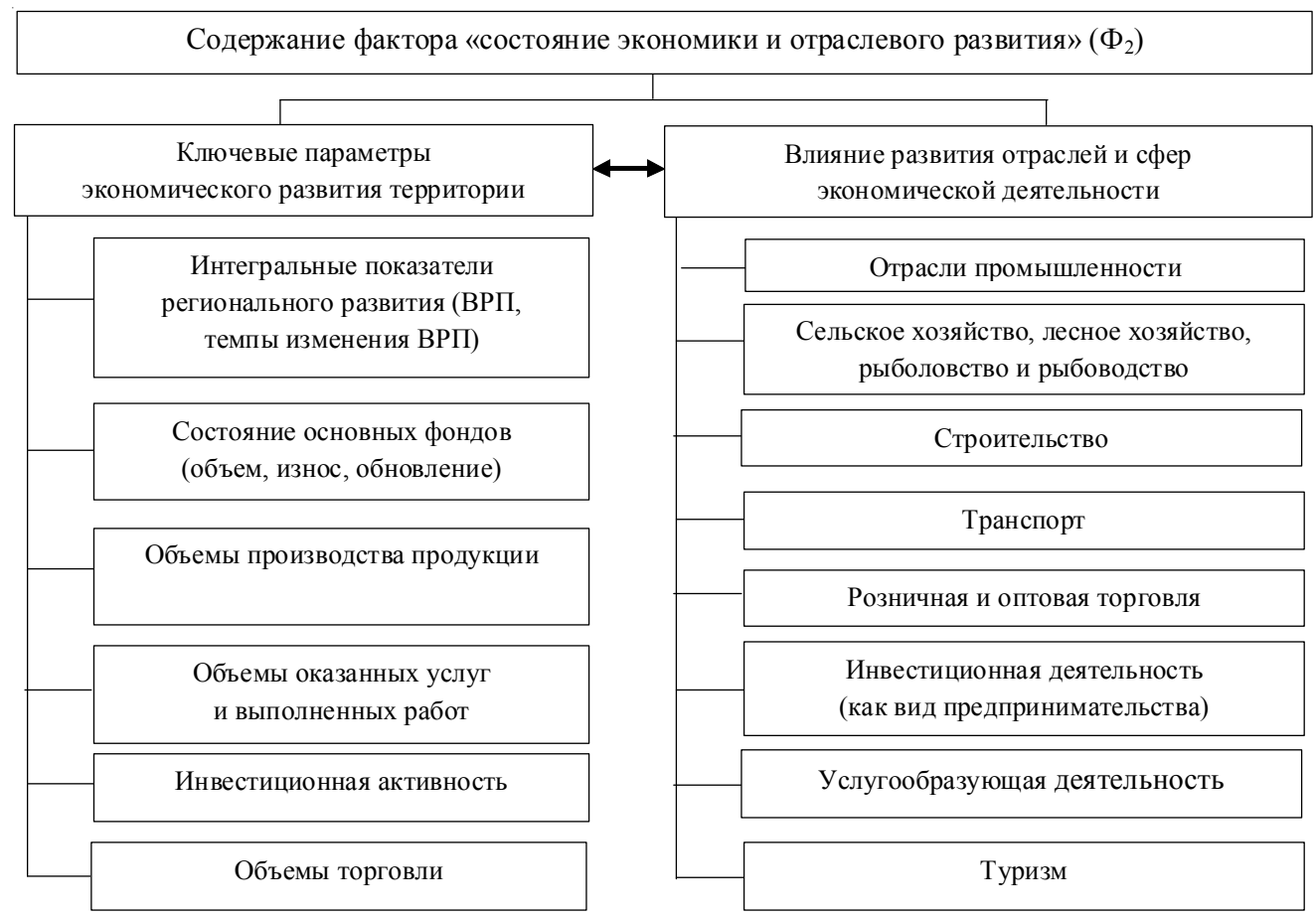

Рис. 3. Содержание элементов фактора социально-экономического развития территории «состояние экономики и отраслевого развития» $\left(\Phi_{2}\right)$

Примечание. Составлено автором. 
С.Б. Болдырева. Значение туризма в системе факторов социально-экономического развития региона

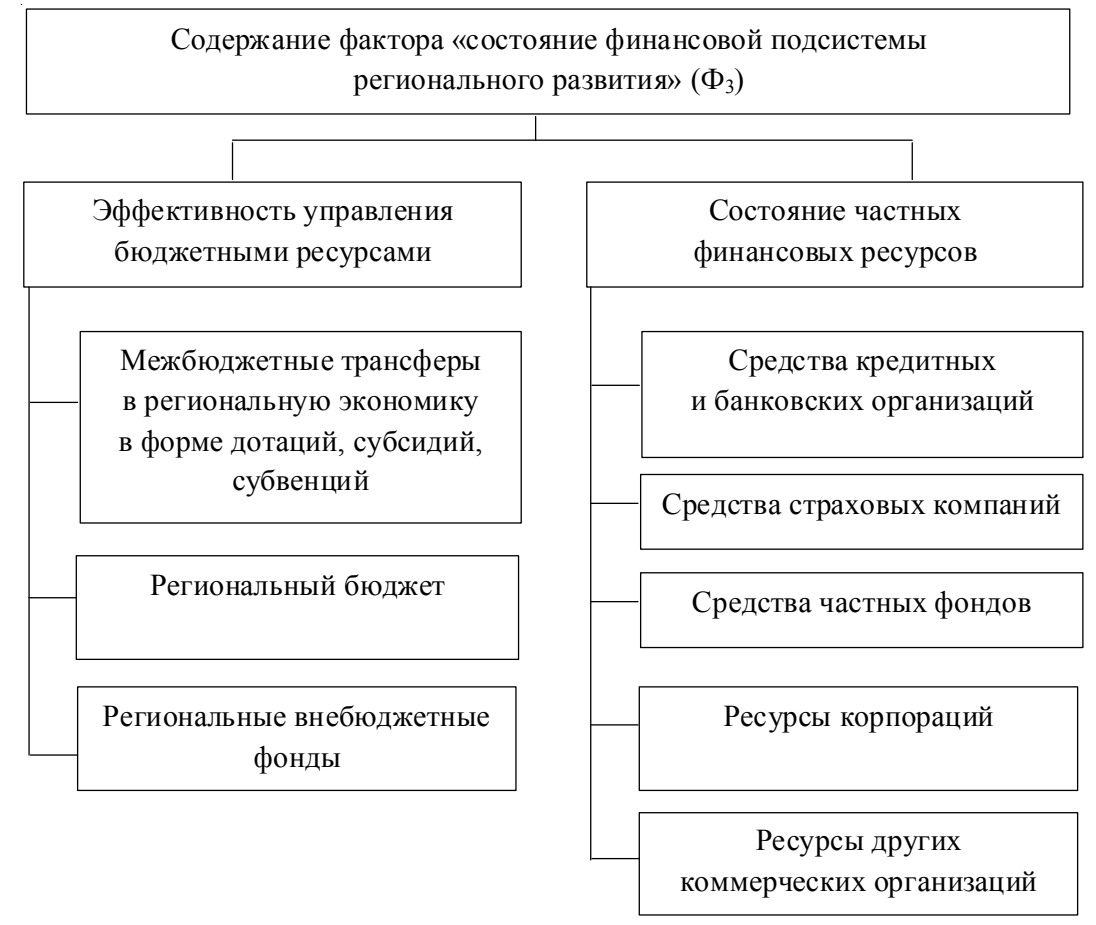

Рис. 4. Содержание элементов фактора социально-экономического развития территории «состояние финансовой подсистемы региона» $\left(\Phi_{3}\right)$

Примечание. Составлено автором. сунке 5 .

Содержание фактора приведено на ри-

К управляемым факторам социальноэкономического развития территории следует также относить состояние объектов материальной и нематериальной инфраструктуры (см. рис. 6).

К самостоятельному и управляемому фактору социально-экономического развития территорий нами отнесена демографическая структура и демографическая ситуация (см. рис. 7).

Социальные и культурные условия (фактор $\Phi_{6}$ авторской классификации факторов социально-экономического развития) тесно связаны между собой, в связи с чем включены в отдельную самостоятельную группу. Социальные условия могут выражаться:

1) уровнем жизни населения в регионе, в том числе:

- объемами доходов, расходов и сбережений населения;

2) состоянием социального обеспечения и социальной помощи населению; ления;

3) структурой доходов и расходов насе-

4) уровнем бедности;
5) потребительскими ожиданиями;

6) состоянием сфер образования и здравоохранения;

7) жилищными условиями и прочими составляющими данный фактор компонентами.

Культурные условия характеризуют влияние на социально-экономическое развитие сложившихся и складывающихся в регионе системы ценностей, отношения населения к различным сферам деятельности, проблемам и вопросам регионального развития.

Тесно взаимосвязан с указанными выше факторами выделенный в самостоятельную, управляемую группу - политико-правовой и институциональный фактор (фактор $\Phi_{7}$ ). Данный фактор отражает состояние эффективного правового регулирования и институционального обеспечения ключевых для социальноэкономического развития региона сфер. Кроме этого, учитывается влияние политических процессов, сказывающихся:

- на политике регионального развития;

- фискальной политике;

- налоговой политике;

- социальной политике;

- инвестиционной политике и др. 


\section{РЕГИОНАЛЬНАЯ ЭКОНОМИКА}

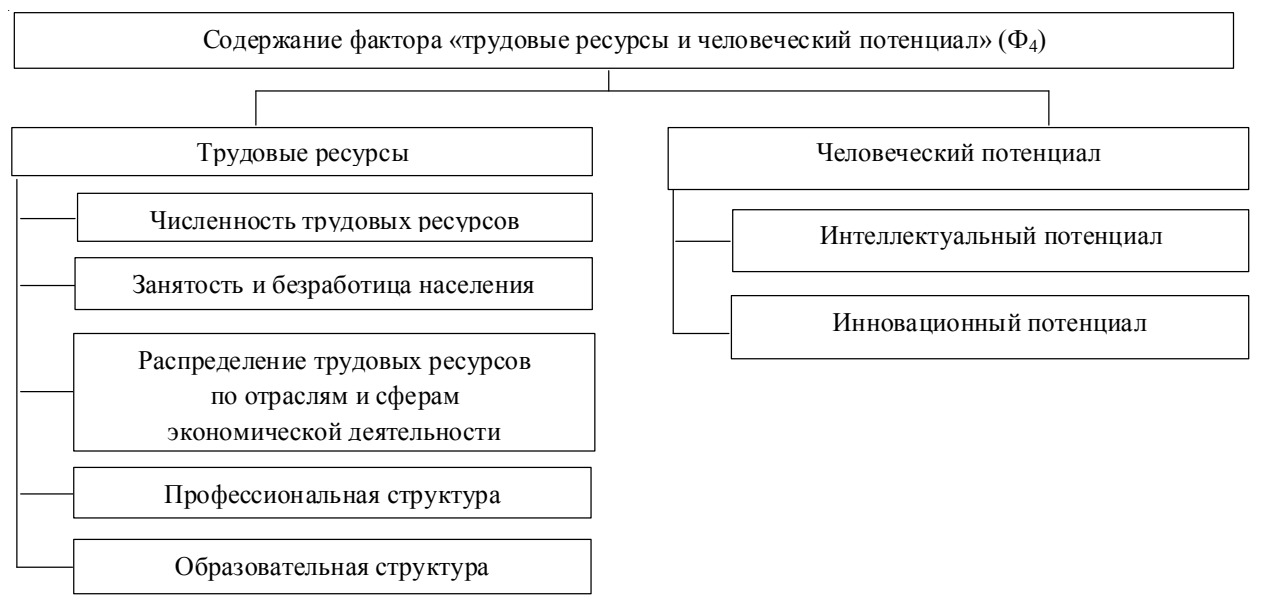

Рис. 5. Содержание элементов фактора социально-экономического развития территории «трудовые ресурсы и человеческий потенциал» $\left(\Phi_{4}\right)$

\section{Примечание. Составлено автором.}

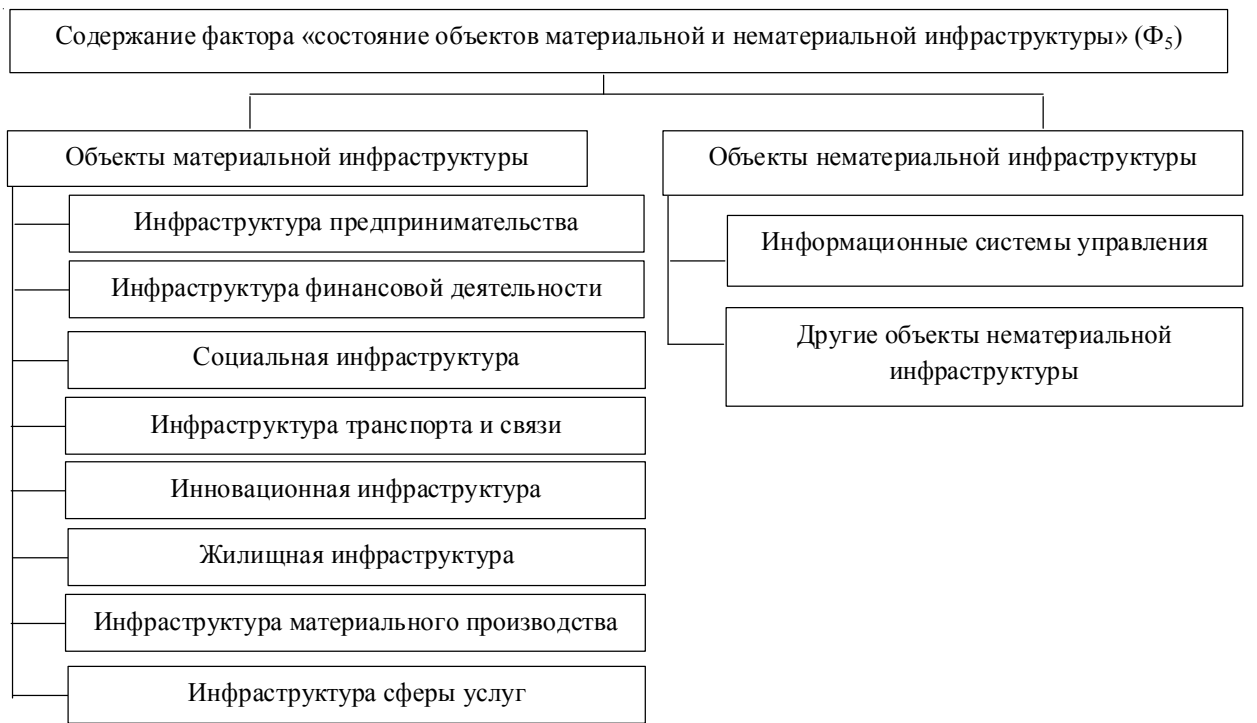

Рис. 6. Содержание элементов фактора социально-экономического развития территории «состояние объектов материальной и нематериальной инфраструктуры» $\left(\Phi_{5}\right)$

Примечание. Составлено автором.

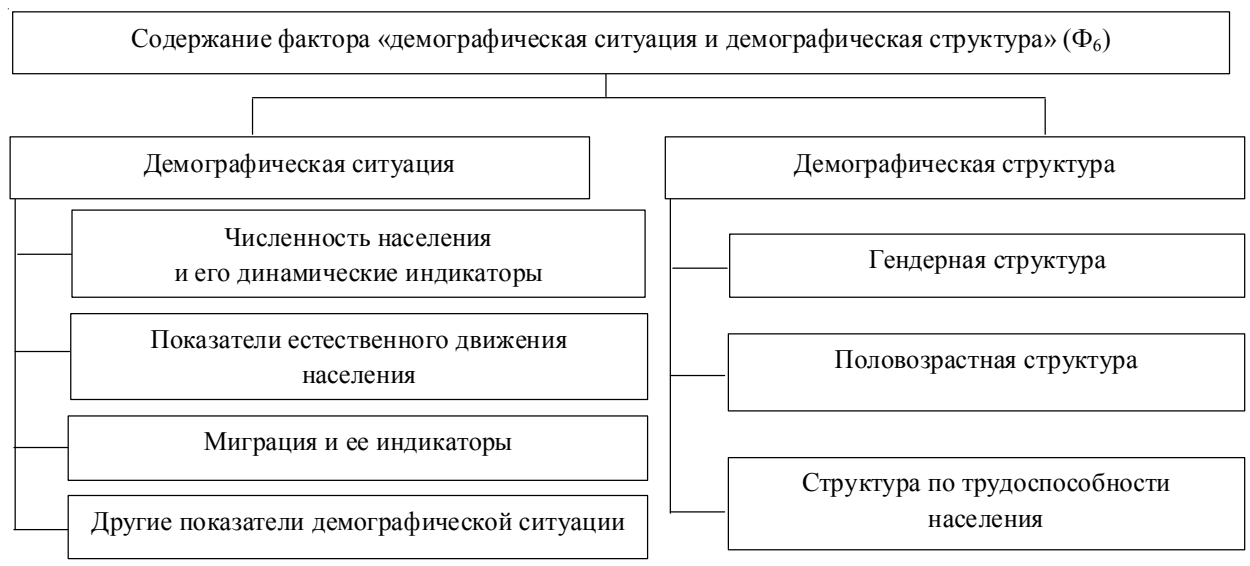

Рис. 7. Содержание элементов фактора социально-экономического развития территории «состояние объектов материальной и нематериальной инфраструктуры» $\left(\Phi_{6}\right)$

Примечание. Составлено автором. 
С.Б. Болдырева. Значение туризма в системе факторов социально-экономического развития региона

К числу неконтролируемых факторов социально-экономического развития нами отнесены территориальное положение (географический фактор $\Phi_{9}$ ) и природно-климатические условия (фактор $\Phi_{10}$ ).

Территориальное положение, являясь неконтролируемым фактором, может оказывать существенное влияние на уровень социальноэкономического развития региона. В частности, имеют значение следующие условия:

- близость или отдаленность региона к государственным границам, статус региона по данному признаку (приграничный, неприграничный);

- близость или отдаленность региона к крупным транспортным и торгово-экономическим международным коридорам;

- близость или отдаленность региона от деловых, культурных, промышленных центров;

- близость или отдаленность региона от значимых природных объектов и др.

К природно-климатическим условиям регионального развития можно отнести климатические особенности, способные оказать или оказывающие благотворное или, наоборот, негативное влияние на социально-экономическое развитие региона. Кроме этого, на уровень социально-экономического развития региона оказывают влияние природные и рекреационные ресурсы.

Среди тенденций современности, на которые стоит обратить внимание при выборе источников экономического роста регионов, можно выделить:

1. Взаимонаправленное стремление широких слоев населения и государственных органов создать условия для комфортной жизнедеятельности, времяпрепровождения и перемещения граждан между территориями.

2. Стремление общества к рационализации использования природных и рекреационных ресурсов.

3. Высвобождение за счет роста производительности труда, использования новых технологий, изменения структуры национальной и региональной экономик, дополнительного времени на отдых у граждан.

4. Изменения в культуре и системе ценностей населения, обусловленные влиянием идей «общества потребления», проявляющиеся в постоянном стремлении повысить качество и уровень жизни.
5. Повышение мобильности населения ввиду роста уровня транспортных технологий, появления новых маршрутов и транспортных сетей.

В таких условиях отраслью, способной стать источником социально-экономического развития региона, становится туризм.

Значение туризма, как фактора социально-экономического развития региона, характеризуется в научных исследованиях через преимущества, предоставляемые данной отраслью региональной экономики.

Л.Ю. Прозурин к числу преимуществ туризма, позволяющих отнести его к факторам сбалансированного, динамичного социально-экономического развития, относит высокий уровень доходности отрасли и интенсивное развитие ее отдельных направлений [11]. Растущий спрос на путешествия различной направленности и рентабельность туристических продуктов также выступают обстоятельствами, говорящими в пользу значимости туризма в социально-экономическом развитии региона [7, с. 181]. Кроме того, отрасль туризма играет значимую роль в увеличении доходов государственного бюджета различных уровней [8], доходы, полученные операторами туристической отрасли, участвуют в международном и региональном движении инвестиционного капитала, стимулируют создание новых рабочих мест, обеспечивают рост потребительских расходов.

В работе [16] влияние туризма на социально-экономическое развитие региона моделируется и оценивается через комплекс основных показателей: дохода от всех видов въездного туризма в регион, общего количества посетителей региона, объема внебюджетных инвестиций в инфраструктуру туризма в регионе, доле туризма в валовом региональном продукте региона. Такое понимание влияния туризма на социально-экономическое развитие региона видится несколько ограниченным, поскольку не учитывает таких напрямую обусловленных деятельностью основных и сопутствующих субъектов туристической деятельностью факторов, как:

1. Влияния туризма на финансовую подсистему социально-экономического развития региона, в том числе: 
- через налоговые поступления в региональный и муниципальный бюджеты;

- финансовое состояние предприятий региона, в том числе их доходную и расходную составляющие;

- состояние инвестиционной активности в регионе.

2. Влияния туризма на региональный рынок труда, что проявляется в показателях:

- занятости и безработицы в регионе;

- уровня доходов населения;

- структуры расходов населения региона.

3. Влияния туризма на смежные отрасли и сферы деятельности региональной экономики, в том числе:

- на санаторно-курортную;

- сферу гостиничного хозяйства;

- сферу общественного питания;

- сферу здравоохранения;

- агропромышленный комплекс;

- транспортный комплекс;

- сферу связи;

- сферу торговли;

- строительство;

- производственную сферу.
4. Влияния туризма на состояние инфраструктуры региона, в том числе:

- объектов транспортной инфраструктуры;

- объектов гостиничной инфраструктуры;

- объектов инфраструктуры отдыха;

- объектов инфраструктуры общественного питания;

- объектов спортивной инфраструктуры;

- объектов предпринимательской и торговой инфраструктуры (деловых, торговых центров);

- объектов сопутствующей инфраструктуры: рыночной, финансовой (банковской, страховой), коммунальной, сервисной и др.

Значение туризма в системе факторов социально-экономического развития региона можно проиллюстрировать через основные эффекты данной отрасли экономики, проявляющиеся в рамках каждого отдельного фактора социально-экономического развития территории (рис. 8).

Таким образом, динамичное развитие туризма в последние годы требует обобщения и количественного обоснования в аспекте его влияния на региональную экономику.

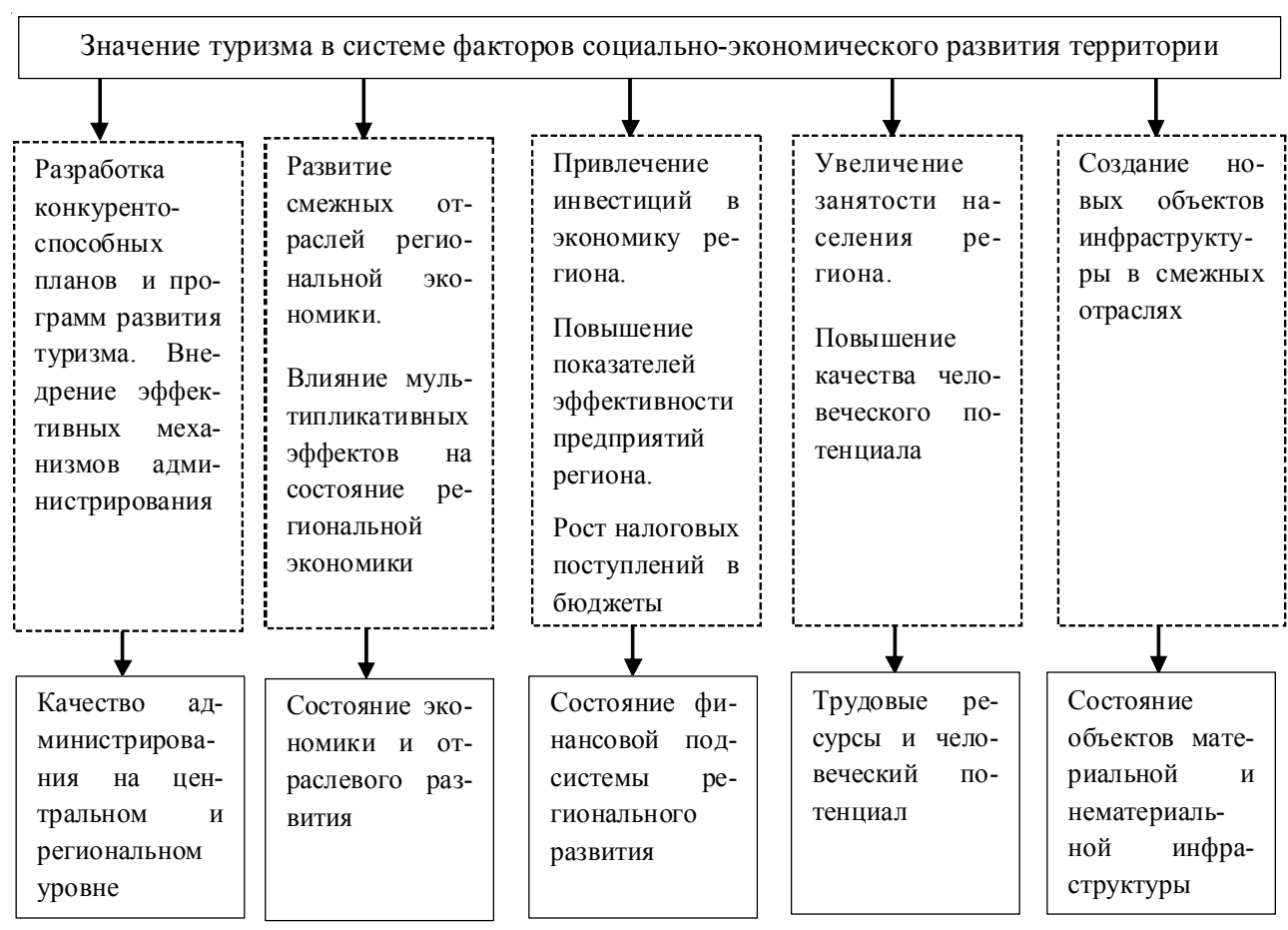

Рис. 8. Проявления роли туризма в системе факторов социально-экономического развития территории Примечание. Составлено автором. 


\section{ПРИМЕЧАНИЕ}

${ }^{1} \Phi_{1}$ - качество администрирования на центральном и региональном уровне; $\Phi_{2}-$ состояние экономики и отраслевого развития; $\Phi_{3}-$ состояние финансовой подсистемы региона; $\Phi_{4}-$ трудовые ресурсы и человеческий потенциал; $\Phi_{5}-$ состояние объектов материальной и нематериальной инфраструктуры; $\Phi_{6}-$ демографическая ситуация и демографическая структура; $\Phi_{7}-$ социальные и культурные условия; $\Phi_{8}-$ политико-правовой и институциональный фактор; $\Phi_{9}-$ территориальное положение (географический фактор); $\Phi_{10}-$ природно-климатические условия.

\section{СПИСОК ЛИТЕРАТУРЫ}

1. Большой толковый словарь русского языка / сост. и гл. ред. С. А. Кузнецов. - СПб. : Норинт, 1998. $-1536 \mathrm{c}$.

2. Большой энциклопедический словарь. Языкознание / гл. ред. В. Н. Ярцева. - М. : Большая рос. энцикл., $2000 .-685 \mathrm{c}$.

3. Гусев, В. В. Совершенствование методического обеспечения устойчивого социально-экономического развития региона на основе его системной диагностики : автореф. дис. ... канд. экон. наук : 08.00.05 / Гусев Валерий Валериевич. - Барнаул, 2014. -26 с.

4. Зайцева, Н. А. Менеджмент в сервисе и туризме : учеб. пособие / Н. А. Зайцева. - 2-е изд., доп. - М. : ФОРУМ, 2009. - 368 c.

5. Игнатьева, Е. Д. Методологические особенности диагностики состояния и развития региональных социально-экономических систем / Е. Д. Игнатьева, О. С. Мариев, А. Е. Ширманова // Вестник Челябинского государственного университета. 2010. - № 14. - С. 97-99.

6. Масюто, И. А. Механизм управления устойчивым развитием экономики региона : автореф. дис. ... канд. экон. наук : 08.00.05 / Масюто Илья Александрович. - Оренбург, 2014. - 24 с.

7. Меркулина, И. А. Роль экологического туризма в социально-экономическом развитии общества / И. А. Меркулина, С. М. Аль Малеки Рассуль // Науковедение : интернет-журн. - 2014. № 5 (24). - С. 181. - Электрон. текстовые дан. - Режим доступа: https://naukovedenie.ru/PDF/152EVN514.pdf (дата обращения: 15.12.2017). - Загл. с экрана.

8. Невейкина, Н. В. Управление устойчивым развитием регионов : методология, теория, инструментарий : автореф. дис. ... д-ра экон. наук : 08.00.05 / Невейкина Надежда Васильевна. - Курск, 2014. - 37 с.

9. Новая парадигма управления социальноэкономическим развитием регионов России : коллектив. науч. моногр. / М. В. Васильева, Т. В. Влади- мирова, Е.В. Романенко, В. П. Часовской ; под общ. ред. М. В. Васильевой // АНО содействия развитию современной отечественной науки Издательский дом «Научное обозрение». - М. : Планета, 2013. - 212 с.

10. Орлова, А. В. Методология оценки устойчивости социально-экономического развития регионов / А. В. Орлова // Современная экономика: проблемы и решения. - 2013. - № 11. - С. 74-78.

11. Прозурин, Л. Ю. Туризм как экономический приоритет / Л. Ю. Прозурин. - М. : Новый век, 2004. $-216 \mathrm{c}$.

12. Региональная экономика : учебник / под ред. В. И. Видяпина и М. В. Степанова. - М. : ИНФРА-М, 2007. $-666 \mathrm{c}$.

13. Скотаренко, О. Концептуальные модели социально-экономического развития регионов / О. Скотаренко // РИСК: Ресурсы, информация, снабжение, конкуренция. -2012. - № 3.-С. 250-253.

14. Татаркин, А. И. Моделирование устойчивого развития как условие повышения экономической безопасности территории / А. И. Татаркин, Д. С. Львов, А. А. Куклин. - Екатеринбург : Изд-во Урал. ун-та, 1999. - 276 с.

15. Указ Президента РФ от 01.04.1996 № 440 «О Концепции перехода Российской Федерации к устойчивому развитию» // Собрание законодательства РФ. - 08.04.1996. - № 15. - Ст. 1572.

16. Ульянченко, Л. А. Теория и методология реализации кластерного подхода в индустрии туризма (на примере Московской области) : дис. ... д-ра экон. наук : 08.00.05 / Ульянченко Людмила Анатольевна. - СПб., 2013. - 294 с.

17. Федеральный закон «О стратегическом планировании в Российской Федерации» от 28.06.2014 № 172-Ф3 // Собрание законодательства РФ. 30.06.2014. - № 26 (ч. I). - Ст. 3378.

18. Феофилова, Т. Ю. Условия развития социально-экономической системы региона / Т. Ю. Феофилова // Ученые записки Российского государственного гидрометеорологического университета. - 2014. - № 36. - С. 162-176.

19. Чуб, А. А. Регион как социально-экономическое образование: факторы устойчивости и институциональные предпосылки развития : дис. ... д-ра экон. наук : 08.00.05 / Чуб Анна Александровна. - Владимир, 2012. - 417 с.

20. Шедько, Ю. Н. Совершенствование механизмов управления устойчивым развитием региона : дис. ... д-ра экон. наук : 08.00.05 / Шедько Юрий Николаевич. - М., 2016. - 361 с.

\section{REFERENCES}

1. Kuznetsov S.A., ed. Bolshoy tolkovyy slovar russkogo yazyka [Great Dictionary of the Russian 
Language]. Saint-Petersburg, Norint Publ., 1998. $1536 \mathrm{p}$.

2. Yartseva V.N., ed. Bolshoy entsiclopedicheskiy slovar. Yazykoznaniye [A Large Encyclopedic Dictionary]. Moscow, Bolshaya Rossiyskaya Encyclopedia Publ., 2000. 685 p.

3. Gusev V.V. Sovershenstvovanie metodicheskogo obespecheniya ustoychivogo sotsialno-economicheskogo razvitiya regiona na osnove ego sistemnoy diagnostiki: aftoref. dis.... cand. econ. nauk: 08.00.05 [Improvement of Methodical Support of Sustainable Social and Economic Development of the Region on the Basis of its System Diagnostics. Cand. econ. sci. abs. diss. : 08.00.05]. Barnaul, 2014. $26 \mathrm{p}$.

4. Zaytseva N.A. Menedzhment $v$ servise $i$ turizme: ucheb. posobie [Management in Service and Tourism: a Tutorial]. 2nd ed. Moscow, FORUM Publ., 2009. 368 p.

5. Ignatyeva E.D., Mariev O.S., Shirmanova A.E. Metodologicheskie osobennosti diagnostiki sostoyaniya i razvitiya regionalnykh sotsialnoeconomicheskikh sistem [Methodological Features of Diagnostics of the State and Development of Regional Socio-Economic Systems]. Vestnik Chelyabinskogo gosudarstvennogo universiteta [Bulletin of the Chelyabinsk State University], 2010, no. 14, pp. 97-99.

6. Masyuto I.A. Mekhanism upravleniya ustoychivym razvitiem economiki regiona: aftoref. dis. ... cand. econ. sciences: 08.00.05 [The Mechanism of Management of Sustainable Development of the Region's Economy: the Author's Abstract. Cand. econ. sci. abs. diss.: 08.00.05]. Orenburg, 2014. 24 p.

7. Merkulina I.A., Al Maleki Rassul S.M. Rol economicheskogo turisma $v$ sotsialno ecnomicheskom razvitii obshchestva [The Role of Ecological Tourism in the Socio-Economic Development of Society]. Naukovedenie: internetzhurn. [Internet-Journal Naukovedenie], 2014, no. 5 (24), pp. 181. URL: https://naukovedenie.ru/PDF/ 152EVN514.pdf(accessed December 15, 2017).

8. Neveykina N.V. Upravlenie ustoychivym razvitiem regionov: metodologiya, teoriya, instrumentariy: avtoref. dis.... d-ra ekon. nauk:08.00.05 [Management of sustainable development of regions: methodology, theory, toolkit. Dr. econ. sci. abs. diss. : 08.00.05]. Kursk, 2014.37p.

9. Novaya paradigma upravleniya sotsialnoekonomicheskim razvitiem regionov Rossii: kollektiv. nauch. monogr [A new paradigm for managing the socioeconomic development of Russia's regions: a collective scientific monograph]. M.V. Vasilyeva, T.V. Vladimirova, E.V. Romanenko, V.P. Chasovskoy, M.V. Vasilyeva, ed. ANO promoting the development of modern Russian science Publishing House "Scientific Review". Moscow, Planeta Publ., 2013.212 p.
10. Orlova A.V. Metodologiya otsenki ustoychivosti sotsialno-ekonomicheskogo razvitiya regionov [Methodology for Assessing the Sustainability of Socio-Economic Development of Regions]. Modern economics: problems and solutions, 2013, no. 11, pp. 74-78.

11. Prozurin L.Yu. Turizm kak ekonomicheskiy prioritet [Tourism as an economic priority]. Moscow, New Century Publ., 2004. 216 p.

12. Regionalnaya ekonomika: uchebnik [Regional Economy: Textbook]. Vidyapin V.I., Stepanov M.V., eds. Moscow, Infra-M Publ., 2007. 666 p.

13. Skotarenko O. Kontseptualnye modeli sotsialno-ekonomicheskogo razvitiya regionov [Conceptual Models of Socio-Economic Development of Regions]. RISK: Resources, information, supply, competition, 2012, no. 3, pp. 250-253.

14. Tatarkin A.I., Lvov D.S., Kuklin A.A. Modelirovanie ustoychivogo razvitiya kak uslovie povysheniya ekonomicheskoy bezopasnosti territorii [Modeling of Sustainable Development as a Condition for Increasing the Economic Security of the Territory]. Ekaterinburg, Publishing house Ural. University, 1999. $276 \mathrm{p}$.

15. Ukaz Prezidenta RF ot 01.04.1996 № 440 «O Kontseptsii perehoda Rossiyskoy Federatsii k ustoychivomu razvitiyu» [The decree of the President of the Russian Federation from 01.04.1996 № 440 "About the Concept of transition of the Russian Federation to sustainable development"]. Collection of the legislation of the Russian Federation, 08.04.1996, no. 15, art. 1572.

16. Ulyanchenko L.A. Teoriya i metodologiya realizatsii klasternogo podhoda v industrii turizma (na primere Moskovskoy oblasti): dis. ... d-ra ekon. nauk: 08.00.05 [Theory and methodology for implementing the cluster approach in the tourism industry (by the example of the Moscow region). Dr. econ. sci. abs. diss.: 08.00.05]. St. Petersburg, 2013. 294 p.

17. Federalnyy zakon «O strategicheskom planirovanii v Rossiyskoy Federatsii» ot 28.06.2014 № 172-FZ [Federal Law "On Strategic Planning in the Russian Federation" of June 28, 2014 No. 172-FZ]. Collection of Legislation of the Russian Federation, June 30, 2014, no. 26 (part I), art. 3378.

18. Feofilova T.Yu. Usloviya razvitiya sotsialnoekonomicheskoy sistemy regiona [Conditions for the development of the social and economic system of the region], 2014, no. 36, pp. 162-176.

19. Chub A.A. Region kak sotsialnoekonomicheskoe obrazovanie: faktory ustojchivosti $i$ institutsionalnye predposylki razvitiya: dis. ... d-ra ekon. nauk: 08.00.05 [Region as a socio-economic entity: factors of sustainability and institutional preconditions for development. Dr. econ. sci. abs. diss.: 08.00.05]. Vladimir, 2012.417p. 
С.Б. Болдырева. Значение туризма в системе факторов социально-экономического развития региона

20. Shedko Yu.N. Sovershenstvovanie mekhanizmov upravleniya ustoychivym razvitiem regiona: dis. ... d-ra ekon. nauk: 08.00.05 [Perfection of mechanisms of management of steady development of region: the dissertation. Dr. econ. sci. abs. diss.: 08.00.05]. Moscow, 2016. $361 \mathrm{p}$.

\section{Information about the Author}

Saglara B. Boldyreva, Candidate of Sciences (Economics), Associate Professor, Head of Department of Management, Kalmyk State University named after B.B. Gorodovikova, Microdistr. 5, Bld. 7/409, 358000 Elista, Russian Federation, boldyreva_sb@mail.ru, https://orcid.org/0000-0002-7416-4839

\section{Информация об авторе}

Саглара Борисовна Болдырева, кандидат экономических наук, доцент, заведующая кафедрой менеджмента, Калмыцкий государственный университет им. Б.Б. Городовикова, 5 мкр-н, учебный корпус 7, каб. 409, 358000 г. Элиста, Российская Федерация, boldyreva_sb@mail.ru, https:/ /orcid.org/0000-0002-7416-4839 